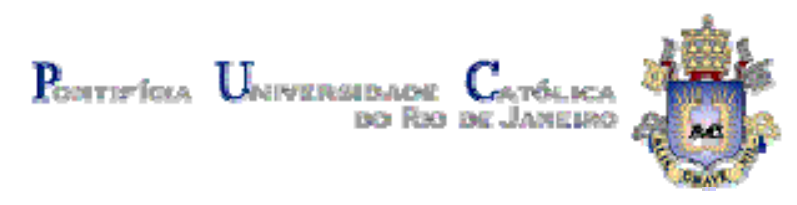

Pedro Navarro Cesar

O Modelo Dedutivo na Teoria do Raciocínio Jurídico de Neil MacCormick

Dissertação de Mestrado

Dissertação apresentada ao Programa de Pós-Graduação em Direito da PUCRio como requisito parcial para a obtenção do título de Mestre em Direito.

Orientador: Antonio Carlos Cavalcanti Maia 


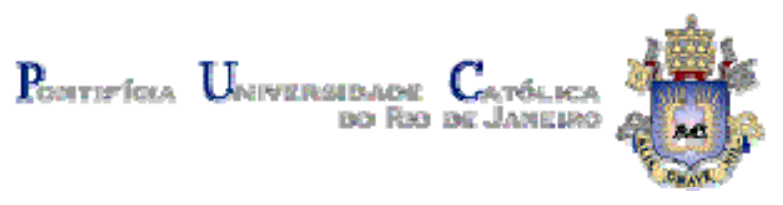

Pedro Navarro Cesar

\section{O Modelo Dedutivo na Teoria do Raciocínio Jurídico de Neil MacCormick}

Dissertação de Mestrado

Dissertação apresentada ao Programa de PósGraduação em Direito da PUC-Rio como requisito parcial para a obtenção do título de Mestre em Direito.

Prof. Antonio Carlos Cavalcanti Maia

Orientador

Departamento de Direito - PUC-Rio

Prof. Adrian Sgarbi

Departamento de Direito - PUC-Rio

Prof. Noel Struchiner

Departamento de Direito - UFRJ

Prof. João Pontes Nogueira

Coordenação Setorial de Pós-Graduação e Pesquisa - PUC-Rio

Rio de Janeiro, 4 de setembro de 2006 
Todos os direitos reservados. É proibida a reprodução total ou parcial do trabalho sem autorização da universidade, do autor e do orientador.

\section{Pedro Navarro Cesar}

Graduou-se em Direito pela Faculdade de Direito da Universidade do Estado do Rio de Janeiro em 2003. É advogado no Rio de Janeiro.

Ficha Catalográfica

Cesar, Pedro Navarro

O modelo dedutivo na teoria do raciocínio jurídico de Neil MacCormick / Pedro Navarro Cesar ; orientador: Antonio Carlos Cavalcanti Maia. - Rio de Janeiro: PUC, Departamento de Direito, 2006.

115 f. ; $30 \mathrm{~cm}$

Dissertação (mestrado) - Pontifícia Universidade Católica do Rio de Janeiro, Departamento de Direito.

Inclui referências bibliográficas.

1. Direito - Teses. 2. Neil MacCormick. 3. Lógica. 4. Dedução. 5. Silogismo Hipotético. 7. Justificação de Primeira e de Segunda Ordem. 8. Raciocínio Jurídico. 9. Argumentação. I. Maia, Antonio Carlos Cavalcanti. II. Pontifícia Universidade Católica do Rio de Janeiro. Departamento de Direito. III. Título. 


\section{Agradecimentos}

Ao meu orientador, professor Antonio Cavalcanti Maia, pela inestimável ajuda prestada e pelas inúmeras oportunidades oferecidas.

Aos demais professores integrantes do Programa de Pós-Graduação em Direito da PUC-Rio, pelo incentivo e enriquecimento intelectual.

À PUC-Rio e à Capes, pelo indispensável auxílio financeiro.

Aos funcionários da PUC-Rio, Carmen, Anderson e Marcos, pela presteza e auxílio nas horas de necessidade.

Ao amigo José Guilherme, por tornar possível a preparação deste trabalho e pelas inúmeras conversas construtivas.

Aos amigos Carlos Frederico e Pedro Peterson, que, embora à distância, contribuíram significativamente para a elaboração deste trabalho.

À Candice, companhia maravilhosa, que soube suportar com carinho e bom humor essa etapa. 


\section{Resumo}

Cesar, Pedro Navarro; Maia, Antonio Carlos Cavalcanti. O Modelo Dedutivo na Teoria do Raciocínio Jurídico de Neil MacCormick. Rio de Janeiro, 2006. 115 p. Dissertação de Mestrado - Departamento de Direito, Pontifícia Universidade Católica do Rio de Janeiro.

Em 1978, Neil MacCormick publica o livro Legal Reasoning and Legal Theory com o principal objetivo de construir uma teoria do raciocínio jurídico (legal reasoning) descritiva e normativa que fosse compatível com o positivismo jurídico de H. L. A. Hart. O método utilizado para apresentar a teoria parte da reconstrução racional de casos concretos pré-selecionados. A análise das decisões judiciais oferece comprovações empíricas às teses de MacCormick e também indica o foco de sua teoria sobre o raciocínio jurídico: o estudo do processo de justificação judicial. É com base neste enfoque que o autor estabelece a divisão entre justificação de primeira ordem (first-order justification) e justificação de segunda ordem (second-order justification). A presente dissertação analisa apenas a justificação de primeira ordem, que está relacionada com a correção formal do raciocínio judicial. O modelo adotado para avaliar essa característica é a dedução, em especial o silogismo hipotético misto dos lógicos tradicionais. Para o autor escocês, a decisão judicial que lograr subsumir as variáveis do caso concreto nos componentes universais do fato operativo da regra jurídica, derivando como conclusão a conseqüência normativa daquela regra, estará justificada em um Estado que promove a legalidade (Rule of Law).

\section{Palavras-chave}

Neil MacCormick, lógica, dedução, silogismo hipotético, justificação de primeira e de segunda ordem, raciocínio jurídico, argumentação. 


\section{Abstract}

Cesar, Pedro Navarro; Maia, Antonio Carlos Cavalcanti. The Deductive Model in Neil MacCormick's Theory of Legal Reasoning. Rio de Janeiro, 2006. 115 p. Masters Monograph - Law Department, Pontifícia Universidade Católica do Rio de Janeiro.

In 1978, Neil MacCormick published the book Legal Reasoning and Legal Theory with the goal of constructing a descriptive and normative theory of legal reasoning, compatible with the legal positivism of H. L. A. Hart. The author used the rational reconstruction of concrete pre-selected cases as the method to present his theory. The analysis of judicial decisions offers empirical backing to MacCormick's theses and highlights the focus of his theory of legal reasoning: the study of the process of legal justification. Based on this focus, the author establishes the split between first-order justification and second-order justification. This dissertation only analyzes the first-order justification, which is related with the formal correction of legal reasoning. The model adopted to evaluate this characteristic is deduction, especially the mixed hypothetical syllogism of traditional logicians. According to the Scottish author, the judicial decision that attempts to subsume the variables of the concrete case in the universal components of the operative fact of the legal rule, coming to the conclusion of a normative consequence of that same rule, will be justified in a State that promotes the Rule of Law.

\section{Keywords}

Neil MacCormick, logic, deduction, hypothetical syllogism, first and second-order justifications, legal reasoning, argumentation. 


\section{Sumário}

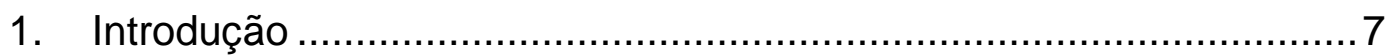

2. O Método da Reconstrução Racional .........................................13

2.1. Rule of Law e o Modelo Dedutivo .....................................20

3. O Modelo Dedutivo na Obra de MacCormick.............................. 28

3.1. As Regras Jurídicas e o Modelo Dedutivo ........................... 35

4. A Força Justificatória do Modelo Dedutivo ................................... 48

4.1. Natureza Cogente e Impositiva da Conclusão Dedutiva ...........51

4.2. O Silogismo Hipotético Misto .........................................54

4.3. O Silogismo Hipotético Misto Aplicado ao Direito ....................59

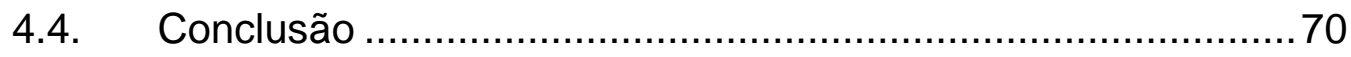

5. Formalização Lógica do Raciocínio Jurídico .............................. 73

5.1. Lógica Proposicional ou Lógica Predicativa? ........................74

6. É Possível Aplicar a Lógica ao Direito?...................................... 82

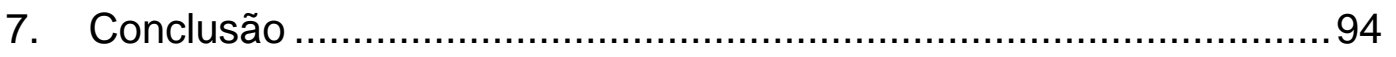

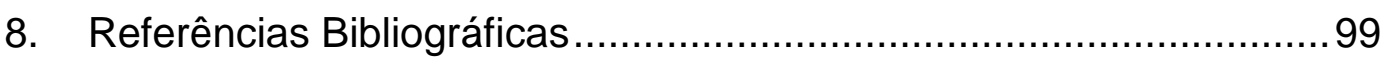

